\title{
DISKRESI PENGELOLAAN BAGIAN ANGGARAN BENDAHARA UMUM NEGARA BELANJA LAINNYA (BA 999.08) DALAM KERANGKA KEUANGAN NEGARA
}

Ari Setyowibowo

Sekretariat Ditjen Perbendaharaan

Alamat korespondensi: ari.van.java@gmail.com

\section{INFORMASI ARTIKEL}

Diterima Pertama

09 Mei 2017

Dinyatakan Diterima

30 Juli 2018

KATA KUNCI:

Discretion, Policy, AUPB, Finance, Treasury,

KLASIFIKASI JEL:

E14, H5

\begin{abstract}
Policy of budget management of the State General Treasurer of Others Expenditure Budget (BA 999.08) is one of the policies that taken by the Minister of Finance of Indonesia as fiscal's manager to execute one of the State Treasurer function in the management of the state budget as the purpose of provisions in the Package of Act on Finance State along with the operational regulations. Because of the characteristics that are different from the general state budget management, Minister of Finance has given the authority to regulate further discretionarie policy related to budget management of the State General Treasurer of Others Expenditure Budget. The implementation of policy in the management of the General Treasurer of Others Expenditure Budget needs to be done according to the rules of the legislation and adhere to the General Principles of Good Governance (AUPB) also the principles of public finance management in order to meet the state budget management aspects of effective and efficient, transparent, fair, professional, and also accountable in the corridors of state law.
\end{abstract}

\section{ABSTRAK}

Kebijakan pengelolaan Bagian Anggaran Bendahara Umum Negara Belanja Lainnya (BA 999.08) merupakan salah satu kebijakan yang dilakukan oleh Menteri Keuangan selaku pengelola fiskal dalam menjalankan salah satu fungsi Bendahara Umum Negara di bidang pengelolaan anggaran negara sebagaimana maksud ketentuan dalam paket undang-undang di Bidang Keuangan Negara beserta aturan hukum pelaksanaannya. Oleh karena karakteristiknya yang berbeda dengan anggaran belanja negara pada umumnya, Menteri Keuangan diberikan kewenangan discretionarie untuk mengatur lebih lanjut kebijakan terkait pengelolaan anggaran BA 999.08 dimaksud. Pelaksanaan kebijakan dalam pengelolaan anggaran BUN Belanja Lainnya tersebut perlu dilakukan sesuai peraturan perundang-undangan serta mematuhi Asas-asas Umum Pemerintahan yang Baik (AUPB) maupun prinsip-prinsip pengelolaan keuangan negara guna memenuhi aspek pengelolaan anggaran negara yang efektif dan efisien, transparan, adil, profesional, serta akuntabel dalam koridor negara hukum. 


\section{PENDAHULUAN}

\subsection{Latar Belakang}

Salah satu bentuk tindakan pemerintah yang dilakukan demi mendukung terwujudnya tata kelola pemerintahan yang baik adalah dibuatnya aturan hukum dan kebijakankebijakan demi terciptanya pengelolaan keuangan negara yang baik, transparan, dan akuntabel. Pengelolaan keuangan negara adalah keseluruhan kegiatan pejabat pengelola keuangan negara sesuai dengan kedudukan dan kewenangannya, yang meliputi perencanaan, pelaksanaan, pengawasan, dan pertanggungjawaban ${ }^{1}$.

Ketentuan terkait pengelolaan keuangan negara mengacu pada paket undang-undang di bidang keuangan negara yakni, UU Nomor 17 Tahun 2003 tentang Keuangan Negara, UU Nomor 1 Tahun 2004 tentang Perbendaharaan Negara, dan UU Nomor 15 Tahun 2004 tentang Pemeriksaan Pengelolaan dan Tanggung Jawab Keuangan Negara, serta aturan hukum lain sebagai peraturan pelaksanaan yang terkait dengan pengelolaan keuangan negara.

Dalam Penjelasan Umum UU Nomor 17 Tahun 2003, disebutkan bahwa Menteri Keuangan sebagai pembantu Presiden di bidang fiskal, merupakan Bendahara Umum Negara (BUN) yang diibaratkan sebagai Chief Financial Officer (CFO) Pemerintah Republik Indonesia, sementara Menteri/Pimpinan Lembaga sebagai Chief Operational Officer (COO) untuk suatu bidang tertentu pemerintahan.

Menteri/Pimpinan Lembaga selaku Pengguna Anggaran (PA) memiliki kewenangan penggunaan Bagian Anggaran Kementerian Negara/Lembaga untuk kementerian negara/lembaga yang dipimpinnya. Dalam ketentuan Pasal 1 angka 4 Peraturan Pemerintah Nomor 90 Tahun 2010 tentang Penyusunan Rencana Kerja dan Anggaran Kementerian/Lembaga disebutkan bahwa Bagian Anggaran merupakan kelompok anggaran menurut nomenklatur Kementerian/Lembaga dan menurut fungsi Bendahara Umum Negara. Menteri Keuangan, dalam kapasitasnya sebagai salah satu menteri teknis, juga memiliki kewenangan untuk menggunakan Bagian Anggaran untuk kementerian yang dipimpinnya.

1 Muhammad Djafar Saidi, Hukum Keuangan Negara, Edisi Revisi (Jakarta: Rajawali Press, Cet. Ke-4, 2014), hlm. 21.
Selain Bagian Anggaran untuk kementerian yang dipimpinnya, Menteri Keuangan, selaku Bendahara Umum Negara juga memiliki kewenangan sebagai Pengguna Anggaran untuk Bagian Anggaran Bendahara Umum Negara (BA 999). Bagian Anggaran Bendahara Umum Negara (BA BUN) merupakan bagian anggaran yang tidak dikelompokkan dalam bagian anggaran Kementerian/Lembaga dan digunakan untuk membiayai pengeluaran yang sifatnya mendesak dan/atau tidak terduga. Rincian pembagian Bagian Anggaran BUN, sebagaimana tercantum dalam Lampiran IV Peraturan Presiden Nomor 36 Tahun 2015 tentang Rincian Anggaran Pendapatan dan Belanja Negara Tahun 2015, adalah sebagai berikut:

1. BA BUN Pengelolaan Utang Pemerintah (BA 999.01)

2. BA BUN Pengelolaan Hibah (BA 999.02)

3. BA BUN Pengelolaan Belanja Subsidi (BA 999.07)

4. BA BUN Pengelolaan Belanja Lainnya (BA 999.08)

5. BA BUN Pengelolaan Transaksi Khusus (BA.999.99)

Dari pembagian dimaksud, tanggung jawab Menteri Keuangan selaku PA BA BUN berbeda antara pelaksanaan kegiatan yang menjadi tugas dan fungsi Kementerian Keuangan dengan pelaksanaan kegiatan yang bukan merupakan tugas dan fungsi Kementerian Keuangan. Berdasarkan ketentuan Pasal 4 Peraturan Pemerintah Nomor 45 Tahun 2013 tentang Tata Cara Pelaksanaan Anggaran Pendapatan dan Belanja Negara, pelaksanaan tanggung jawab Menteri Keuangan selaku PA atas bagian anggaran yang tidak dikelompokkan dalam bagian anggaran Kementerian Negara/Lembaga tertentu diatur sebagai berikut:

1. Dalam hal kegiatan yang dibiayai bukan merupakan tugas dan fungsi Kementerian Keuangan, Menteri Keuangan hanya bertanggung jawab secara formal; dan

2. Dalam hal kegiatan yang dibiayai merupakan tugas dan fungsi Kementerian Keuangan, Menteri Keuangan bertanggung jawab secara formal dan materiil sesuai dengan ketentuan Peraturan Perundangundangan.

Tanggung jawab formal dalam pelaksanaan kegiatan merupakan tanggung 
jawab atas pengelolaan keuangan Kementerian Negara/Lembaga yang dipimpinnya, sementara tanggung jawab materiil merupakan tanggung jawab atas penggunaan anggaran, dan hasil yang dicapai (output) atas beban anggaran negara. Dari keempat rincian jenis BA BUN di atas, poin 1 s.d. 3 serta poin 5 merupakan bagian dari tugas dan fungsi Kementerian Keuangan, sedangkan poin 4 (BA BUN Pengelolaan Belanja Lainnya) mencakup kegiatan-kegiatan di luar tugas dan fungsi Kementerian Keuangan dan pelaksanaannya tersebar dalam tugas dan fungsi Kementerian/Lembaga.

Dalam praktik pelaksanaannya, Menteri Keuangan selaku Pengguna Anggaran BA BUN telah mengeluarkan peraturan kebijakan tekait prosedur penggunaan anggaran BA BUN Pengelolaan Belanja Lainnya (BA 999.08) melalui Peraturan Menteri Keuangan Nomor 87/PMK.02/2015 tentang Tata Cara Penggunaan Anggaran Bagian Anggaran Bendahara Umum Negara Pengelolaan Belanja Lainnya (BA 999.08) (sebelumnya, diatur dalam Peraturan Menteri Keuangan Nomor 155/PMK.02/2013).

Selain kebijakan terkait mekanisme penggunaan dana, dalam praktik pelaksanaan pengunaan dana BA 999.08, Menteri Keuangan juga mengeluarkan kebijakan-kebijakan untuk mengatur pelaksaanaan kegiatan yang dibiayai melalui pos anggaran BA 999.08. Sebagai contoh, kebijakan untuk pelaksanaan kegiatan yang dibiayai melalui pos anggaran BA 999.08 adalah kegiatan Ongkos Angkut Beras bagi Pegawai Negeri Sipil (PNS) di Distrik Pedalaman Provinsi Papua dan Papua Barat yaitu, Peraturan Menteri Keuangan Nomor 207/PMK.02/2014 tentang Tata Cara Penyediaan, Pencairan, dan Pertanggungjawaban Dana ongkos Angkut Beras untuk Pegawai Negeri Sipil Distrik Pedalaman Provinsi Papua dan Provinsi Papua Barat. Ongkos angkut beras PNS sebagaimana dimaksud pada PMK tersebut merupakan bantuan biaya pengangkutan beras untuk PNS di pedalaman Papua dan Papua Barat dari gudang Perusahaan Umum (PERUM) BULOG terdekat ke titik serah terdekat di masing-masing tujuan. Dalam ketentuan terkait dana ongkos angkut beras dimaksud, diatur tentang mekanisme pendanaan dan pengelolaan anggaran yang digunakan serta hasil yang dicapai dalam kegiatan ongkos angkut beras untuk PNS di distrik pedalaman Provinsi Papua dan Provinsi Papua Barat.
Apabila ditelaah lebih lanjut, pengaturan dalam pelaksanaan kegiatan yang menggunakan anggaran BA 999.08 tersebut di atas menyebutkan kebijakan terkait peran Menteri Keuangan selaku PA dan Kepala Kanwil Ditjen Perbendaharaan sebagai KPA untuk kegiatan yang tidak secara langsung berhubungan dengan tugas dan fungsi Kementerian Keuangan. Dengan demikian, Menteri Keuangan dalam pengaturan penggunaan anggaran dan pelaksanaan kegiatan dimaksud telah menerapkan kebijakan secara khusus terlepas dari telah adanya ketentuan umum dalam pelaksanaan anggaran.

Diskresi yang dilakukan Menteri Keuangan dalam pengelolaan BA 999.08 sebagaimana tersebut di atas perlu mendapat kajian agar tidak terjadi pemahaman yang keliru tentang konsep diskresi dalam tindakan pemerintahan (bestuurshandeling), dan pemaknaan diskresi yang tepat pada pengelolaan BA 999.08 sebagai bagian dari pengelolaan anggaran negara secara umum dalam kerangka keuangan negara sehingga tidak menimbulkan permasalahan hukum dalam penerapannya. Dengan demikian, pelaksanaannya dapat sesuai dengan ketentuan peraturan perundang-undangan yang ada, sesuai dengan Asas-asas Umum Pemerintahan yang Baik (AUPB) serta secara spesifik sesuai dengan asas-asas pengelolaan keuangan negara.

\subsection{Rumusan Masalah}

a. Asas-asas Umum Pemerintahan yang Baik (AUPB) dalam kebijakan pengelolaan anggaran BA 999.08.

b. Kebijakan pengelolaan anggaran BA 999.08 sebagai diskresi tindakan pemerintahan dalam pengelolaan anggaran negara.

\subsection{Tujuan Penelitian}

Tujuan penelitian ini secara teoritis adalah untuk memberikan analisa yang sistematis dan objektif atas isu hukum yang diangkat sebagaimana rumusan masalah di atas. Sementara, secara praktis diharapkan penelitian ini dapat memberikan priskripsi objektif atas pelaksanaan diskresi pengelolaan anggaran BA 999.08 yang secara normatif, sesuai dengan peraturan perundangan-undangan dan asasasas umum pemerintahan yang baik. 


\section{KERANGKA TEORI}

\subsection{Wewenang dan Diskresi}

Dalam konteks negara hukum Indonesia yang bercorak sistem hukum Civil Law, wewenang penyelenggaraan pemerintahan dan perlindungan hukum bagi rakyat didasarkan pada peraturan perundang-undangan, selain juga pengakuan terhadap hukum kebiasaan dan yurispridensi. Dari sumber-sumber itu, menurut Marzuki (2014) yang menjadi rujukan pertama dalam tradisi hukum sistem civil law adalah peraturan peundang-undangan ${ }^{2}$. Sistem hukum civil law yang berkembang di Indonesia tidak dapat dipisahkan dari pengaruh sistem hukum civil law yang dianut di negara Belanda karena adanya keterkaitan sejarah yang panjang di antara kedua negara.

Hadjon (2011) menyatakan bahwa dalam kepustakan hukum Belanda, soal wewenang selalu menjadi bagian penting dan bagian awal dari hukum administrasi karena obyek hukum administrasi adalah wewenang pemerintahan (bestuurs bevoegdheid) ${ }^{3}$. Dalam istilah bahasa Inggris, kata yang digunakan untuk merujuk pada pengertian wewenang atau kewenangan adalah authority. Black (1990) memberikan pengertian dari kata authority sebagai berikut

legal power; a right to command or to act; the right and power of public officers to require obedience to their orders lawfully issued in scope of their public duties (Black, 1990). 4

Terjemahan bebas dari pengertian authority tersebut adalah sebagai suatu kekuasan legal/hukum, suatu hak untuk memerintah atau untuk bertindak (kepada masyarakat), hak dan kekuasaan pejabat-pejabat publik untuk dipatuhi perintahnya menurut aturan hukum yang berlaku dalam lingkup pelaksanaan tugasnya.

2 Peter Mahmud Marzuki, Pengantar ilmu Hukum, Edisi Revisi (Jakarta: Kencana Pranadamedia, Cet. ke-6, 2014) (selanjutnya disingkat Peter Mahmud Marzuki I), hlm. 259.

3 Philipus M. Hadjon, et al., Hukum Administrasi dan Tindak Pidana Korupsi (Yogyakarta, Gadjah Mada University Press, 2011) (selanjutnya disingkat Philipus M. Hadjon et al., I), hlm. 10.

4 Henry Campbell Black, Black'S Law Dictionary (Minnesotta: West Publishing, 1990, hlm. 133.
Hadjon (1997) menyatakan bahwa ada tiga komponen konsep wewenang sebagai berikut:

Wewenang sebagai konsep hukum publik sekurang-kurangnya terdiri dari 3 (tiga) komponen, yaitu pengaruh, dasar hukum, dan konformitas hukum. Komponen pengaruh ialah bahwa penggunaan wewenang dimaksudkan untuk mengendalikan perilaku subjek hukum. Komponen dasar hukum bahwa wewenang itu selalu harus dapat ditunjuk dasar hukumnya. Komponen konformitas mengandung makna adanya standar wewenang yaitu standar umum (semua jenis wewenang) dan standar khusus (untuk jenis wewenang tertentu). ${ }^{5}$

Sumber wewenang pemerintahan dapat dibedakan atas atribusi dan pelimpahan wewenang. Wewenang atribusi merupakan wewenang yang melekat pada jabatan sementara pelimpahan wewenang dapat dilakukan melalui delegasi dan mandat. Atribusi dari bahasa latin ad tribuere artinya memberikan kepada. Konsep teknis hukum tata negara dan hukum administrasi mengartikan wewenang atribusi adalah wewenang yang diberikan atau ditetapkan untuk jabatan tertentu ${ }^{6}$. Hadjon (2010) menyatakan bahwa pemikiran negara hukum menyebabkan, bahwa apabila penguasa ingin meletakkan kewajiban-kewajiban atas warga (masyarakat), maka kewenangan itu harus ditemukan dalam suatu undang-undang?.

Delegasi berasal dari bahasa Latin delegare yang artinya melimpahkan ${ }^{8}$. Pelimpahan di sini mengandung pengertian bahwa delegasi merupakan kewenangan yang didapatkan oleh organ/jabatan tertentu karena

5 Philipus M. Hadjon, Tentang Wewenang (Surabaya: Yuridika, No. 5 \& 6 Tahun XII, Sep-Des 1997 (selanjutnya disingkat Philipus M . Hadjon I), hlm. 1-2.

6 Philipus M. Hadjon, et al., Hukum Administrasi dan Good Governance (Jakarta: Universitas Trisakti, 2010) (selanjutnya disingkat Philipus M. Hadjon et al., II), hlm. 20.

7 Lihat Philipus M. Hadjon, et al., Pengantar Hukum Administrasi Indonesia, (Yogyakarta: Gadjah Mada University Press, 2010) (selanjutnya disingkat Philipus M. Hadjon et al. III), hlm. 130.

8 Philipus M. Hadjon et al., II, Op.Cit., hlm. 21. 
adanya pelimpahan wewenang dari organ/jabatan lainnya.

Berbeda halnya dengan atribusi dan delegasi, mandat sebenarnya bukanlah bentuk pelimpahan wewenang, tapi lebih sebagai suatu penugasan secara struktural. Mandat berasal dari bahasa latin mandare yang artinya memerintahkan ${ }^{9}$. Sehingga dapat diartikan mandat adalah suatu perintah kedinasan dari pemberi mandat kepada penerima mandat.

Sebagai konsekuensi dari berlakunya konsep negara hukum, setiap wewenang pemerintahan harus dijalankan berdasarkan ketentuan peraturan perundang-undangan (asas legalitas). Namun demikian, seringkali asas legalitas, khususnya dalam ranah hukum administrasi, tidak mampu untuk memenuhi tuntutan negara hukum dalam mewujudkan tujuan kesejahteraan umum. Konsep "bestuur" membawa implikasi kekuasaan pemerintahan tidaklah semata sebagai kekuasaan terikat, tetapi juga merupakan suatu kekuasaan bebas (vrij bestuur, freies ermessen, discretionary power ${ }^{10}$.

Hadjon (2010) menyatakan bahwa untuk memudahkan dalam memberikan pemahaman tentang wewenang bebas atau wewenang diskresi adalah dengan cara melihat ruang lingkupnya yang meliputi:

a. Kewenangan untuk memutus sendiri.

b. Kewenangan interpretasi terhadap norma-norma tersamar (vage normen). ${ }^{11}$

Ridwan HR (2013) menyatakan bahwa dalam praktik penyelenggaraan pemerintahan ada tiga kondisi yang menyebabkan pemerintah dapat melakukan tindakan diskresif, yaitu:

1. Belum ada peraturan perundangundangan yang mengatur tentang penyelesaian in concreto terhadap suatu masalah, padahal masalah

$9 \quad$ Ibid.

10 Philipus M. Hadjon, Discretionary Power dan AsasAsas Umum Pemerintahan Yang Baik (AAUPB), Paper/Makalah, disampaikan pada Seminar Nasional "Aspek Pertanggung jawaban Pidana Dalam Kebijakan Publik Dari Tindak Pidana Korupsi" (Semarang, 2004) (selanjutnya disingkat Philipus M. Hadjon II), h. 1. hlm.3.

11 Lihat Philipus M. Hadjon II, Op. Cit., hlm. 6. tersebut menuntut penyelesaian yang segera.

2. Peraturan perundang-undangan yang menjadi dasar tindakan aparat pemerintah telah memberikan kebebasan sepenuhnya.

3. Adanya delegasi perundangundangan, yaitu pemberian kekuasaan untuk mengatur sendiri kepada pemerintah yang sebenarnya kekuasaan ini dimiliki oleh aparat yang lebih tinggi tingkatannya ${ }^{12}$.

Pemberian ruang pada pemerintah untuk menggunakan wewenanag bebas dapat menimbulkan potensi terjadinya tindakan penyalahgunaan wewenang dengan argumentasi wewenang dimaksud dilakukan untuk kepentingan umum, bersifat mendesak, dan sebagainya. Basah (1997) memberikan pengertian penyalahgunaan wewenang atau "detournement de pouvoir" sebagai berikut:

penyalahgunaan wewenang atau "detournement de pouvoir" adalah perbuatan pejabat yang tidak sesuai dengan tujuan tetapi masih dalam lingkungan ketentuan peraturan perundang-undangan, yang dibedakan dengan tindakan sewenang-wenang "abus de droit" yaitu perbuatan pejabat yang tidak sesuai dengan tujuan dan di luar lingkungan ketentuan perundangundangan 13

Oleh karena itu, diperlukan parameter yang dapat mengukur tindakan pemerintah dalam menggunakan wewenang diskresi untuk menilai keabsahan tindakan yang dilakukan serta menjadi tolok ukur terjadinya penyalahgunaan wewenang atas penggunaan diskresi dari pejabat pemerintah untuk kepentingan pribadi atau golongan. Terkait hal tersebut, Hadjon menyatakan bahwa untuk mendukung asas wetmatigheid [yang terlalu sempit untuk dapat menjangkau wewenang diskresi dengan hanya menggunakan peraturan perundang-undangan sebagai parameter keabsahan], beberapa negara modern

12 Ridwan HR, Hukum Administrasi Negara Edisi Revisi (Jakarta: Rajawali Pers , Cet. 8, 2013) (selanjutnya disingkat Ridwan HR I), hlm. 169.

13 Lihat Sjachran Basah, Eksistensi dan Tolok Ukur Peradilan Administrasi di Indonesia (Bandung: Alumni, 1997), hlm. 223. 
mengembangkan asas rechtmatigheid van bestuur yang mengandung pengertian tindakan pemerintahan berdasarkan hukum secara lebih luas, dengan menggunakan parameter asas-asas umum pemerintahan yang baik (algemene beginselen van behoorlijk bestuur ${ }^{14}$.

Asas-asas Umum Pemerintahan yang Baik (AUPB) lahir dari praktik penyelenggaraan negara dan pemerintahan sehingga bukan produk formal suatu lembaga negara seperti undang-undang ${ }^{15}$. Ridwan HR (2013) dengan mengutip pendapat J.B.J.M. Ten Berge, menyatakan kedudukan AUPB sebagai hukum tidak tertulis di bidang hukum administrasi yang harus dipatuhi, sebagai berikut:

Asas-asas pemerintahan yang patut sebenarnya dikembangkan oleh pengadilan sebagai peraturan hukum mengikat yang diterapkan pada tindakan pemerintah.

Suatu keputusan pemerintah yang bertentangan dengan asas pemerintahan yang baik berarti bertentangan dengan peraturan hukum. Meskipun asas itu berupa pernyataan samar, tetapi kekuatan mengikatnya sama sekali tidak samar: asas ini memiliki daya kerja yang mengikat umum.[italic dari penulis] ${ }^{16}$.

Di Indonesia, perkembangan pengaturan prinsip AUPB menemukan momentumnya yang semakin kuat, tatkala UU Administrasi Pemerintahan disahkan pada tahun 201417. Dalam Undang-Undang Nomor 30 Tahun 2014 tentang Administrasi Pemerintahan, pengaturan tentang AUPB diatur secara khusus pada ketentuan Pasal 10 Ayat (1) dan (2), beserta Penjelasannya.

14 Lihat Philipus M. Hadjon, Beberapa Catatan Tentang Hukum Administrasi, Makalah, tidak dipublikasikan (Surabaya: Fakultas Hukum Universitas Airlangga, tanpa tahun) (selanjutnya disingkat Philipus M. Hadjon III), hlm. 6.

15 Hotma P. Sibuea, Asas Negara Hukum, Peraturan Kebijakan, dan Asas-Asas Umum Pemerintahan yang Baik (Jakarta: Penerbit Erlangga, 2010), hlm.151.

16 Lihat Ridwan HR I, Op. Cit., hlm. 236

17 Lihat Cekli Setya Pratiwi, et. al., Penjelasan Hukum Asas-Asas Umum Pemerintahan yang Baik (AUPB), Hukum Administrasi Negara (Jakarta: Judicial Sector Support Program Mahkamah Agung RI, 2016), hlm. 29.

\subsection{Keuangan Negara dan Anggaran Negara}

Untuk memahami konsep keuangan negara dalam konteks bahasan yuridis, perlu dikemukakan terlebih dahulu tentang istilah keuangan negara dan hukum keuangan negara. Terdapat perbedaan pengertian antara konsep keuangan negara dan hukum keuangan negara. Saidi (2014) memberikan pengertian atas perbedaan tersebut sebagai berikut:

Kedua hal ini (hukum keuangan negara dengan keuangan negara) sangat memiliki perbedaan yang prinsipil, karena hukum keuangan negara membicarakan aspek hukum yang terkait dengan keuangan negara, sementara itu, keuangan negara hanya memberikan aspek teknis yang terkait dengan pengelolaan keuangan negara. Perbedaan hukum keuangan negara dengan keuangan negara terdapat dalam tataran yuridis, sehingga pengertian hukum keuangan negara dengan keuangan negara tidak boleh disamakan. ${ }^{18}$

Untuk memahami aspek yuridis dari keuangan negara, terlebih dahulu akan dibicarakan tentang pengertian keuangan negara. Terdapat beberapa pendapat ahli tentang keuangan negara, Asshiddiqie (2008) mengemukakan lima kriteria untuk memberikan pengertian keuangan negara sebagai berikut:

1. Pengertian pertama dalam arti semua hak dan kewajiban yang menyangkut kekayaan milik negara atau dikuasai oleh negara baik yang berupa uang, barang, atau berupa apa saja yang bernilai ekonomis atau dapat dinilai dengan uang, baik yang bersifat nyata dan konkrit atau masih bersifat potensial atau abstrak;

2. Pengertian kedua dalam arti semua kekayaan milik negara yang dapat dinilai dengan uang dan memiliki nilai buku atau yang termasuk dalam catatan kekayaan akuntansi negara;

3. Pengertian ketiga dalam arti hak dan kewajiban yang menyangkut keuangan atau dana milik negara yang pengelolaannya dilakukan melalui APBN, APBD, dan/atau melalui anggaran perusahaan negara dan perusahaan daerah, serta badanbadan lain, termasuk badan swasta yang mengelola uang negara;

18 Muhammad Djafar Saidi, Op. Cit., hlm.1. 
4. Pengertian keempat dalam arti anggaran pendapatan dan belanja negara, baik tingkat pusat (APBN) ataupun tingkat provinsi dan kabupaten/kota (APBD); dan

5. Pengertian kelima dalam arti anggaran pendapatan dan belanja negara (APBN) tingkat pusat saja. ${ }^{19}$

Dari lima kriteria dimaksud, Asshiddiqie (2008) menyatakan bahwa pengertian keuangan negara yang diadopsi UUD 1945 mengalami perubahan, antara rumusan sebelum amandemen yang menggunakan kriteria kelima, dengan sejak disahkannya Amandemen Ketiga UUD 1945 yang menggunakan kriteria ketiga, sebagai berikut:

Pengertian keuangan negara yang dianut oleh UUD 1945 sejak proklamasi kemerdekaan adalah pengertian yang kelima ini. Namun, setelah reformasi, pengertian yang dianut, seperti yang tercermin dalam rumusan $B A B$ VIII dan BAB VIIIA UUD 1945, bukan lagi pengertian yang kelima tetapi pengertian ketiga yang sangat luas seperti yang tercermin dalam Undang-Undang tentang Keuangan Negara, Undang-Undang tentang Pemeriksaan Pengelolaan dan Tanggung Jawab Keuangan Negara, Undang-Undang tentang Perbendaharaan Negara, dan Undang-Undang tentang Badan Pemeriksa Keuangan. ${ }^{20}$

Lebih lanjut, Saidi (2014) menyatakan:

Ketentuan-ketentuan dalam UndangUndang Dasar 1945 tersebut merupakan sumber hukum keuangan negara, memerlukan penjabaran lebih lanjut dalam bentuk undang-undang. Berarti, perumus Undang-Undang Dasar 1945 memberikan atribusi kepada pembuat undang-undang untuk mengatur substansi yang terkait dengan keuangan negara dalam bentuk undang-undang 21 .

Dari ketentuan UU Nomor 17 Tahun 2003 tentang Keuangan Negara, pengertian keuangan negara tertuang dalam Pasal 1 angka 1:

19 Jimly Asshiddiqie, Pokok-Pokok Hukum Tata Negara Indonesia Pasca Reformasi (Jakarta: Bhuana Ilmu Populer, Cet. II, 2008), hlm. 819-820.

20 Ibid., hlm. 819.

21 Muhammad Djafar Saidi, Op. Cit., hlm.5.
Keuangan Negara adalah semua hak dan kewajiban negara yang dapat dinilai dengan uang, serta segala sesuatu baik berupa uang maupun berupa barang yang dapat dijadikan milik negara berhubung dengan pelaksanaan hak dan kewajiban tersebut. Dengan melihat substansi pengertian keuangan negara yang dikaitkan dengan pengaturan dalam UUD 1945, maupun atribusi yang diberikan untuk penyusunan undang-undang yang memuat ketentuan lebih lanjut terkait Keuangan Negara, dapat dilihat aspek yuridis yang terkait dengan pengelolaan keuangan Negara ${ }^{22}$.

Dalam kaitannya dengan bahasan pelaksanaan anggaran negara, maka ketentuan yang relevan untuk dikaji selain Undang-undang Nomor 17 tahun 2003 tentang Keuangan Negara adalah Undang-undang Nomor 1 tahun 2004 tentang Perbendaharaan Negara dan Undangundang tentang APBN yang ditetapkan setiap tahun.

Pelaksanaan anggaran negara merupakan bagian dari suatu siklus anggaran yang terdiri dari perencanaan, pelaksanaan, pengawasan, dan pertanggungjawaban. Siklus anggaran dimulai dengan disusun dan ditetapkannya Undang-undang tentang APBN. Undang-undang dimaksud merupakan dasar hukum diterbitkannya dokumen pelaksanaan anggaran berupa Daftar Isian Pelaksanaan Anggaan (DIPA) yang menjadi dasar Kementerian/Lembaga untuk melakukan pengeluaran anggaran yang bersumber dari dana APBN.

Dalam pelaksanaannya, anggaran negara dapat mengalami perubahan maupun pergeseran. Konsep perubahan anggaran dan pergeseran anggaran haruslah dipahami secara berbeda. Perubahan anggaran merupakan tindakan yang diambil oleh pemerintah bersama dengan DPR untuk melakukan perubahan dalam APBN karena adanya gangguan dalam pelaksanaan anggaran, yang mengakibatkan adanya ketidaksesuaian antara perencanaan penerimaan negara dan realisasi pengeluaran anggaran yang dianggap dapat memengaruhi keseimbangan anggaran negara, dan lebih jauh, mempengaruhi perekonomian nasional. Perubahan anggaran negara harus disesuaikan

22 Lihat ibid. 
dengan perkembangan keadaan dan/atau perubahan [serta disajikan] dalam bentuk undang-undang [Undang-undang tentang APBNPerubahan] ${ }^{23}$.

Selain perubahan APBN, dalam pelaksanaan anggaran negara juga dapat terjadi pergeseran anggaran. Pergeseran anggaran negara adalah tindakan untuk menyesuaikan anggaran negara dalam pelaksanaannya dengan faktor-faktor yang mempengaruhinya, seperti gelombang tsunami di Aceh, gempa bumi di Jawa Tengah, dan banjir bandang di Kabupaten Sinjai, Sulawesi Selatan. ${ }^{24}$ Berbeda dengan perubahan anggaran, pergeseran anggaran dapat dilakukan dengan undang-undang maupun peraturan perundang-undangan di bawah undang-undang. Pergeseran anggaran merupakan bentuk kebijakan yang diambil pemerintah dalam keadaan mendesak yang membutuhkan penanganan segera dengan meggunakan anggaran negara. Mengenai hal ini, Saidi (2014) menyatakan bahwa pergeseran anggaran merupakan bentuk freis ermessen yang dilakukan dalam keadaan force majeur.

Pergeseran anggaran negara tidak boleh dilakukan ketika tidak berada dalam keadaan force majeur terhadap suatu kegiatan yang memerlukan pembiayaan yang secara mendesak dan harus ditanggulangi secara seketika saat itu. Pelaksanaan pergeseran anggaran negara merupakan freis ermessen yang berada pada pengelola keuangan negara, baik di tingkat pusat maupun di daerah yang pembiayaannya bersumber dari anggaran negara. Kebijakan itu tetap berada dalam lingkup koridor hukum, artinya freis ermessen tidak boleh dilakukan tatkala menyimpang atau bertentangan dengan ketentuan peraturan perundang-undangan yang berlaku. ${ }^{25}$

\section{Metodologi Penelitian}

\subsection{Tipe Penelitian}

Penelitian ini merupakan penelitian hukum yang bertujuan menemukan kebenaran koherensi. Marzuki (2015) menyatakan bahwa

\footnotetext{
23 Ibid., hlm.64.

24 Ibid., hlm. 65.

25 Ibid., hlm. 66-67.
}

yang dimaksud penelitian hukum bertujuan menemukan kebenaran koherensi, yaitu adakah aturan hukum sesuai norma hukum dan adakah norma yang berupa perintah atau larangan itu sesuai dengan prinsip hukum, serta apakah tindakan (act) seseorang sesuai dengan norma hukum (bukan hanya sesuai aturan hukum) atau prinsip hukum ${ }^{26}$. Lebih lanjut, dikatakan bahwa penelitian hukum untuk karya akademis juga harus menemukan preskripsi yang dapat diterapkan dan koheren dengan prinsip hukum yang merefleksikan moral ${ }^{27}$.

\subsection{Pendekatan Masalah}

Penelitian ini dilakukan dengan menggunakan dua pendekatan, yaitu pendekatan undang-undang (Statute Approach), dan pendekatan konseptual (Conceptual Approach). Pendekatan undang-undang (statute approach) dilakukan dengan menelaah semua undang-undang dan regulasi yang bersangkut paut dengan isu hukum yang sedang ditangani ${ }^{28}$. Hadjon (2015) menyatakan bahwa langkah dasar pola nalar yang dikenal sebagai reasoning based on rules adalah penelusuran peraturan perundang-undangan ${ }^{29}$. Oleh karena itu, pendekatan ini dilakukan dengan menelaah peraturan-peraturan perundang-undangan yang berkaitan dengan permasalahan hukum yang dihadapi guna mendapatkan solusi atas masalah hukum yang dihadapi tersebut.

Pendekatan yang kedua adalah Pendekatan konseptual (Conseptual Approach). Untuk memahami norma, harus diawali dengan memahami konsep ${ }^{30}$. Pendekatan konseptual beranjak dari pandangan-pandangan dan doktrin-doktrin yang berkembang di dalam ilmu hukum $^{31}$. Dengan mempelajari pengertianpengertian dan doktrin-doktrin hukum yang

26 Lihat Peter Mahmud Marzuki, Penelitian Hukum, Edisi Revisi (Jakarta: Kencana Prenadamedia Group, Cet. Ke-10, 2015) (selanjutnya disingkat Peter Mahmud Marzuki II), hlm. 47.

27 Ibid., hlm. 81-82.

28 Ibid., hlm. 133.

29 Lihat Philipus M. Hadjon dan Tatiek Sri Djatmiati, Argumentasi Hukum (Yogyakarta: Gajah Mada University Press, Cet. III, 2008, hlm. 42.

$30 \quad$ Ibid, hlm. 42-43.

31Peter Mahmud Marzuki II (2015), Op. Cit., hlm. 135. 
terkait dengan masalah hukum yang dihadapi, diharapkan akan dapat memudahkan dalam memahami permasalahan hukum yang dihadapi tersebut.

\subsection{Sumber Bahan Hukum}

Sumber bahan hukum yang digunakan pada penelitian ini terdiri dari bahan hukum primer dan bahan hukum sekunder. Bahan hukum primer, merupakan bahan hukum yang bersifat autoritatif, artinya mempunyai otoritas $^{32}$. Bahan hukum primer yang digunakan diantaranya adalah Undang-Undang Dasar (UUD), Undang-Undang/Peraturan Pemerintah Pengganti Undang-Undang, Peraturan Pemerintah, serta peraturan-peraturan pelaksanaan lainnya, yang terkait dengan isu hukum yang dibahas. Sedangkan sumber hukum sekunder yang akan digunakan berupa segala bentuk publikasi tentang hukum yang bukan merupakan suatu dokumen resmi seperti bukubuku teks/literatur, penelitian hukum, makalah hukum, jurnal ilmiah, serta bahan sekunder non hukum untuk mengetahui perkembangan terkini yang berkaitan dengan sasaran penelitian seperti dari surat kabar, website, dan media lainnya.

\subsection{Pengumpulan Bahan hukum}

Marzuki (2015) menyatakan bahwa dalam penelitian hukum, begitu isu hukum ditetapkan, perlu dilakukan penelusuran untuk mencari bahan-bahan hukum yang relevan terhadap isu hukum yang dihadapi ${ }^{33}$. Setelah seluruh bahan hukum tersebut terkumpul, selanjutnya dilakukan pengelompokkan berdasarkan tema kajian untuk kemudian dianalisis dan dirumuskan secara sistematis berdasarkan pendekatan penelitian yang digunakan.

\section{HASIL PENELITIAN}

\subsection{Asas-asas Umum Pemerintahan yang Baik (AUPB) dalam Kebijakan Pengelolaan Anggaran BA 999.08}

Sebagai konsekuensi bentuk negara hukum, setiap wewenang pemerintah harus dijalankan berdasarkan ketentuan peraturan perundang-undangan (asas legalitas). Dalam hukum administrasi asas legalitas dalam

\footnotetext{
32 Ibid., hlm.181.

33 Lihat ibid., hlm.237.
}

wujudnya wetmatigheid van bestuur, sudah lama dirasakan tidak memadai ${ }^{34}$.

Asas wetmatighid van bestuur dianggap kurang memadai karena pada praktiknya, kekuasaan pemerintah tidaklah sekadar sebagai kekuasaan eksekutif untuk melaksanakan undang-undang yang disusun legislatif/parlemen. Konsep "bestuur" membawa implikasi kekuasaan pemerintahan tidaklah semata sebagai kekuasaan terikat, tetapi juga merupakan suatu kekuasaan bebas (vrij bestuur, freies ermessen, discretionary power $)^{35}$.

Ruang lingkup diskresi pemerintah itu berkenaan dengan implementasi atau penjelasan secara detail dan lebih spesifik norma umum dan abstrak undang-undang (uitleg van wettelijke voorschriften), menafsirkan norma samar (vage norm), dan terbuka (open texture) yang terdapat dalam undang-undang (wetsinterpretatie), mengambil pilihan dari beberapa alternatif yang ada, mempertimbangkan berbagai kepentingan terkait, dan bahkan membuat norma untuk penyelenggaraan urusan pemerintahan ketika berhadapan dengan masalah-masalah yang belum ada aturannya atau tidak ada undangundang yang mengaturnya (leemten in hei recht) ${ }^{36 .}$.

Sibuea (2010), dengan mengutip pendapat Prajudi Atmosudirjo, menyatakan:

Dalam hukum administrasi dikenal dua macam diskresi yaitu diskresi terikat dan diskresi bebas. Pembedaan tersebut ditetapkan berdasarkan tolok ukur ruang kebebasan yang diberikan undangundang kepada pemerintah atau pejabat administrasi negara dalam mengambil inisiatif sendiri, yaitu dalam diskresi terikat, undang-undang memberikan pembatasan atas ruang pertimbangan pemerintah, sedangkan dalam diskresi bebas, undang-undang tidak membatasi secara khusus pemerintah untuk melakukan pertimbangan dan hanya

34 Philipus M. Hadjon II (2004), Op. Cit., hlm. 1.

35 Ibid., hlm.3.

36 Ridwan HR, Diskresi dan Tanggung Jawab Pemerintah (Yogyakarta: FH UUI Press, 2014) (selanjutnya disingkat Ridwan HR II), hlm. 141. 
mengatur batas-batas umum sehingga pemerintah dapat mengambil keputusan apapun sepanjang tidak melampaui atau melanggar batas-batas yang bersifat umum tersebut ${ }^{37}$.

Dalam pelaksanaan kegiatan pemerintahan, konsep asas diskresi (freies ermessen) tidak bisa dilepaskan dari keberadaan peraturan kebiijakan (beleidsregels). Asas diskresi dan peraturan kebijakan merupakan substansi yang berbeda, tetapi memiliki hubungan yang sangat erat dalam lingkungan hukum administrasi negara ${ }^{38}$.

Dalam konteks Indonesia, beleidsregels muncul dalam berbagai peraturan pelaksanaan yang bersifat praktis. Hadjon (2010) menyatakan bahwa produk semacam peraturan kebijaksanaan tidak terlepas dari penggunaan freies ermessen, yaitu badan atau pejabat tata usaha negara yang bersangkutan merumuskan kebijaksanaannya itu dalam berbagai bentuk "jurisdische regel", seperti peraturan, pedoman, pengumuman, dan surat edaran dan mengumumkan kebijaksanaan ${ }^{39}$.

Berbeda dengan wewenang terikat (wewenang yang berasal dari peraturan perundang-undangan) yang dapat diukur dengan peraturan perundang-undangan yang mengatur wewenang dimaksud, asas "wetmatigheid" tidaklah memadai untuk menggunakan peraturan perundang-undangan sebagai satu-satunya parameter yang digunakan dalam mengukur diskresi. Oleh karena itu, parameter yang digunakan adalah Asas-asas Umum Pemerintahan yang Baik (AUPB). AUPB lahir dari praktik penyelenggaraan negara dan pemerintahan, sehingga bukan produk formal suatu lembaga negara seperti undang-undang (Sibuea, 2010) ${ }^{40}$.

Negara hukum Indonesia yang demokratis sebagai pancaran dari suatu pemerintahan rakyat, realisasinya, secara fungsional dilakukan oleh hukum administrasi

37 Lihat Hotma P. Sibuea, Op.Cit., hlm.79.

38 Ibid., hlm. 90.

39 Philipus M. Hadjon et al., Pengantar Hukum Administrasi Indonesia (Yogyakarta: Gadjah Mada University Press, 2010) (selanjutnya disingkat Philipus M. Hadjon et al. II), hlm. 152.

40 Hotma P. Sibuea, Op. Cit., hlm.151.
Indonesia beserta asas-asas umum penyelenggaraan pemerintahan yang baik sebagai ujung tombaknya, atau sebagai juridische-instrumentarium-nya, sehingga dengan konstruksi demikian akan mengalir wewenang istimewa badan/pejabat administrasi Indonesia terhadap rakyat dan pelaksanaan dari wewenang tersebut tetap berada dalam koridor hukum administrasi ${ }^{41}$. Memperhatikan hal tersebut, setiap tindakan diskresi badan publik yang diwujudkan dalam pembentukan peraturan kebijakan sebagai pelaksanaan dari wewenang bebas badan/pejabat administrasi, tetaplah harus mengacu pada koridor hukum administrasi. Demikian halnya dengan penyusunan peraturan kebijakan di bidang hukum keuangan negara, dalam hal ini, terkait pengelolaan anggaran Bendahara Umum Negara untuk Bagian Anggaran Pengelolaan Belanja Lainnya, kiranya juga mengacu pada prinsip-prinsip hukum administrasi.

Wewenang Menteri Keuangan dalam pengelolaan anggaran Bendahara Umum Negara merupakan pelaksanaan dari wewenang atribusi Menteri Keuangan selaku pengelola fiskal dan Bendahara Umum Negara sebagaimana diatur dalam Pasal 8 huruf $\mathrm{f}$ Undang-undang Nomor 17 Tahun 2003 tentang Keuangan Negara jo. Pasal 7 Undang-undang Nomor 1 Tahun 2004. Selanjutnya dalam Peraturan Pemerintah Nomor 90 Tahun 2010, Pasal 110 menyebutkan tentang ketentuan lebih lanjut mengenai pelaksanaan anggaran Bendahara Umum Negara untuk pos belanja lain-lain (dalam hal ini BA 999.08) diatur dengan Peraturan Menteri Keuangan.

Meskipun kedua Peraturan Pemerintah tersebut telah mendelegasikan pengaturan tentang pengelolaan BA 999.08, tidak disebutkan secara jelas batasan sejauh mana pengaturan yang dapat dilakukan Menteri Keuangan dalam pengelolaan anggaran dimaksud. Oleh karena itu, sebagaimana salah satu syarat pendelegasian wewenang yang disampaikan Hadjon (1997) ${ }^{42}$, diperlukan peraturan kebijakan (beleidsregel) untuk memberikan instruksi (petunjuk) tentang penggunaan wewenang yang didelegasikan

41 Lihat S.F. Marbun, Asas-Asas Umum Pemerintahan Yang Layak (Yogyakarta: FH UII Press, 2014), hlm. 27.

42 Lihat syarat-syarat wewenang delegasi sebagaimana disampaikan dalam Philipus $\mathrm{M}$. Hadjon I (1997), Op.Cit., hlm. 7. 
tersebut. Berkenaan hal tersebut, dalam pengelolaan Anggaran Bendahara Umum Negara untuk Belanja Lainnya (BA 999.08), Menteri Keuangan dengan kewenangannya untuk mengmbil kebijakan (beleidsvrijheid) dan mempertimbangkan (beordelingsvrijheid), mengeluarkan Peraturan Menteri Keuangan Nomor 87/PMK.02/2015 tentang Tata Cara Penggunaan Anggaran Bagian Anggaran Bendahara Umum Negara Pengelolaan Belanja Lainnya (BA 999.08).

Beberapa ketentuan yang diatur dalam Peraturan Menteri Keuangan Nomor 87/PMK.02/2015, antara lain:

1. Kegiatan-kegiatan yang dapat dibiayai dengan anggaran BA 999.08.

2. Pihak-pihak yang dapat menyampaikan usulan penggunaan dana kepada Menteri Keuangan.

3. Kriteria pengajuan penggunaan anggaran yang perlu dipenuhi untuk kegiatan-kegiatan yang sifatnya mendesak.

4. Pengecualian atas kriteria pengajuan penggunaan anggaran untuk kegiatankegiatan dalam keadaan-keadaan tertentu dengan persetujuan Menteri Keuangan.

5. Syarat-syarat administratif pengajuan penggunaan dana.

6. Pengajuan Kuasa Pengguna Anggaran serta tanggung jawab formal dan material terkait penggunaan dana.

Selain kebijakan terkait mekanisme penggunaan dana, dalam praktik pelaksanaan pengunaan dana BA 999.08, Menteri Keuangan juga mengeluarkan kebijakan-kebijakan untuk mengatur pelaksaanaan kegiatan yang dibiayai melalui pos anggaran BA 999.08. Sebagai contoh, untuk kegiatan bantuan dana pengangkutan beras PNS di Distrik Pedalaman Provinsi Papua dan Papua Barat, yang pembiayaannya dilakukan melalui BA 999.08, Menteri Keuangan mengeluarkan Peraturan Menteri Keuangan Nomor 207/PMK.02/2014 tentang Tata Cara Penyediaan, Pencairan, dan Pertanggungjawaban Dana ongkos Angkut Beras untuk Pegawai Negeri Sipil Distrik Pedalaman Provinsi Papua dan Provinsi Papua Barat. Dalam ketentuan terkait dana ongkos angkut beras dimaksud, diatur tentang mekanisme pendanaan dan pengelolaan anggaran yang digunakan serta hasil yang dicapai dalam kegiatan ongkos angkut beras untuk Pegawai
Negeri Sipil di distrik pedalaman Provinsi Papua dan Provinsi Papua Barat. Secara garis besar, PMK dimaksud mengatur hal-hal sebagai berikut:

1. Menteri Keuangan selaku Pengguna Anggaran BA.999.08 menunjuk Kepala Kanwil Direktorat Jenderal Perbendaharaan Provinsi Papua dan Kepala Kanwil Diektorat Jenderal Perbendaharaan Provinsi Papua Barat selaku Kuasa Pengguna Anggaran (KPA).

2. KPA diberikan kewenangan untuk menunjuk Pejabat Pembuat Komitmen (PPK) dan Pejabat Penandatangan Surat Perintah Membayar (PPSPM) yang berasal dari lingkungan Pemerintah Daerah Provinsi Papua dan Papua Barat.

3. KPA berwenang mengajukan usulan penggunaan anggaran dana ongkos angkut beras kepada Menteri Keuangan.

4. Usulan penggunaan dana dari KPA menjadi dasar bagi Menteri Keuangan untuk menerbitkan Daftar Isian Pelaksanaan Anggaran (DIPA).

5. Peran dan tanggung jawab pihak-pihak yang terlibat dalam kegiatan ongkos angkut beras.

Berdasarkan uraian PMK terkait pengaturan mekanisme penggunaan anggaran Bendahara Umum Negara Belanja Lainnya, serta contoh PMK terkait pelaksanaan kegiatan yang dibiayai dengan anggaran Belanja Lainnya (BA 999.08), dapat dilihat unsur diskretionarie pada kebijakan Menteri Keuangan dari pengaturan tersebut sebagai berikut:

1. Wewenang Menteri Keuangan dalam pengelolaan bagian anggaran Bendahara Umum Negara sebagaimana diatur dalam PP Nomor 90 Tahun 2010 jo. PP Nomor 45 Tahun 2013 tidak secara spesifik mengatur tentang pengelolaan Belanja Lainnya (BA 999.08) sehingga PP dimaksud memberikan kewenangan Menteri Keuangan untuk mengambil kebijakan lebih lanjut dalam mengatur pengelolaan Belanja Lainnya (BA 999.08).

2. Dalam PMK Nomor 87/PMK.02/2015, Menteri Keuangan selain mengatur mengenai kegiatan dan syarat pengajuan anggaran BA 999.08, juga diatur terkait keadaan-keadaan tertentu yang dapat mengecualikan prosedur penggunaan anggaran BA 999.08 setelah mendapat persetujuan Menteri Keuangan. 
3. Dalam pelaksanaan kegiatan ongkos angkut beras, Menteri Keuangan menunjuk Kepala Kanwil Ditjen Perbendaharaan Kementerian Keuangan selaku KPA, meskipun kegiatan dimaksud bukan merupakan bagian dari tugas dan fungsi Kementerian Keuangan.

4. Dalam penunjukan para pejabat perbendaharaan dalam kegiatan ongkos angkut beras terdapat keterlibatan Gubernur Papua dan Papua Barat dalam pelaksanaan kegiatan meskipun yang bersangkutan tidak termasuk sebagai salah satu pejabat perbendaharaan yang ditunjuk.

Memperhatikan uraian terkait kebijakan pengelolaan anggaran Bendahara Umum Negara khususnya untuk pengelolaan Belanja Lainnya, terdapat beberapa kebijakan Menteri Keuangan yang diambil secara mandiri. Oleh karenanya, untuk menguji ketepatan sisi keabsahan kebijakan dimaksud perlu dilakukan kajian baik dari sisi wetmatiegheid terkait peraturan perundang-undangan yang mendasari sebagaimana tersebut di atas, juga sisi rechtmatiegheid/keabsahan tindakan pemerintahan dengan parameter Asas-asas Umum Pemerintahan yang Baik (AUPB) yang dipakai sebagai tolok ukur/parameter diskresi/kebijakan tindakan pemerintahan.

Berdasarkan berbagai pendapat ahli, dalam lingkup hukum administrasi, pengujian peraturan kebijakan merupakanaspek doelmatigheid dengan batu uji AUPB/algemeen beginselen van belworlijk bestuur, terutama asas larangan penyalahgunaan wewenang (verbod van detournement de pouvoir), dan larangan bertindak sewenang-wenang (verbod van willekeur) ${ }^{43}$. AUPB, yang dipahami sebagai suatu asas hukum yang secara umum diakui dan dijadikan sebagai dasar dalam penyelenggaraan pemerintahan agar berjalan dengan yang baik, berkembang dari pendapat para ahli dan praktik-praktik dalam peradilan administrasi. Purbopranoto (1975) ${ }^{44}$, dengan melengkapi pendapat Crince Le Roy, menyatakan asas dalam AUPB, yaitu:

asas kepastian hukum (principle of legal security); asas keseimbangan (principle of proportionality); asas kesamaan dalam

43 Ridwan HR II, Op. Cit., hlm. 67.

44 Lihat Kuntjoro Purbopranoto, Beberapa Catatan Hukum Tata Pemerintahan dan Peradilan Administrasi Negara (Bandung: Bina Cipta, 1975), hlm. 29-30 mengambil keputusan (principle ofequality); asas bertindak cermat (principle of carefulness); asas motivasi dalam setiap keputusan (principle of motivation); asas larangan mencampuradukkan kewenangan (principle of nonmisuse of competence); asas permainan yang layak (principle affair play); asas keadilan atau kewajaran (principle ofreasonable ofprohibition of arbitrariness); asas menanggapi penghargaan yang wajar (principle of meeting raised expectation); asas meniadakan akibat keputusan yang batal (principle of undoing the consequence of unnulled decision); asas perlindungan atas pandangan (cara) hidup pribadi (principle of protecting the personal way of life). Selanjutnya,

Purbopranoto menambahkan 2 asas lain yang dianggap sesuai dengan konteks hokum Indonesia yaitu asas kebijaksanaan (principle of sapiently) dan asas penyelenggaraan kepentingan umum (principle of public service $)^{45}$.

Sementara itu, apabila dikaitkan dengan AUPB sebagaimana diatur dalam ketentuan Pasal 10 UU Nomor 30 Tahun 2014 tentang Administrasi Pemerintahan, sebagai cerminan AUPB yang telah berkembang dan diakui sebagai instrumen yuridis formal di Indonesia, serta penerapannya dalam pengelolaan BA 999.08 dapat diuraikan AUPB sebagai berikut:

\section{Asas Kepastian Hukum}

Sebagai landasan wewenang pemerintahan dalam negara hukum, pengaturan oleh Menteri Keuangan terkait pengelolaan BA 999.08 menjadi landasan ketentuan peraturan perundang-undangan dalam pengelolaan anggaran negara yang belum secara spesifik diatur dalam ketentuan umum pengelolaan anggaran negara yang telah ada.

\section{Asas Kemanfaatan}

Manfaat yang diperoleh dari pengaturan pengelolaan BA 999.08 harus diperhatikan secara seimbang antara pihak pemerintah selaku pengelola anggaran, pelaksana kegiatan, maupun warga masyarakat penerima output anggaran, maupun pihak-pihak lainnya yang terkait dengan pengelolaan anggaran dimaksud.

\section{Asas Ketidakberpihakan}

45 Lihat Sibuea, Op. Cit., hlm. 159 
Dalam pengambilan kebijakan pengelolaan anggaran, Menteri Keuangan harus bertindak dengan mempertimbangkan kepentingan para pihak yang terkait dengan kebijakan dimaksud secara keseluruhan dan tidak diskriminatif.

\section{Asas Kecermatan}

Menteri Keuangan harus secara cermat mempertimbangkan dan mempersiapkan kebijakannya dengan didasarkan pada informasi dan dokumen yang lengkap untuk mendukung legalitas penerapan kebijakan dimaksud.

\section{Asas Tidak Menyalahgunakan Kewenangan}

Dalam pengambilan kebijakan, Menteri Keuangan dilarang untuk menggunakan kewenangannya untuk kepentingan pribadi atau kepentingan yang lain dan tidak sesuai dengan tujuan pemberian kewenangan tersebut. Dalam kajian hukum administrasi, penyalahgunaan wewenangi berkenaan dengan asas spesialitas yang secara substansial bermakna bahwa setiap kewenangan memiliki tujuan tertentu. Djatmiati $(2004)^{46}$ menyatakan bahwa asas spesialitas ini (specicdialiteits beginsel), yang diterjemahkan sebagai asas tujuan, merupakan suatu asas yang menjadi landasan bagi kewenangan pemerintah untuk bertindak dengan mempertimbangkan pada suatu tujuan tertentu, sehingga penyimpangan asas ini dapat melahirkan penyalahgunaan wewenang atau "détournement de pouvoir".

\section{Asas Keterbukaan}

Terhadap kebijakan yang telah ditetapkan, Menteri Keuangan harus menjamin adanya keterbukaan masyarakat untuk mendapatkan akses dan memperoleh informasi yang benar, jujur, dan tidak diskriminatif atas pelaksanaan kebijakan dimaksud dengan tetap memperhatikan perlindungan atas hak asasi pribadi, golongan, dan rahasia negara.

\section{Asas Kepentingan Umum}

Tujuan utama penyelenggaraan pemerintahan dalam konteks negara kesejahteraan adalah pemenuhan kesejahteraan umum. Pun demikian dengan kebijakan pemerintah dalam pengelolaan anggaran Belanja Lainnya, harus mengutamakan kesejahteraan dan kemanfaatan

46 Lihat Tatiek Sri Djatmiati, Prinsip-prinsip Izin Usaha Industri di Indonesia, Disertasi (Surabaya: Program Pasca Sarjana Universitas Airlangga, 2004), hlm. 108. umum dengan cara yang aspiratif, akomodatif, selektif, dan tidak diskriminatif.

\section{Asas Pelayanan Yang Baik}

Pengaturan dalam kebijakan pengelolaan anggaran Belanja Lainnya harus mencerminkan pelayanan yang tepat waktu, prosedur dan biaya yang jelas (apabila ada), sesuai dengan standar pelayanan, dan ketentuan peraturan perundangundangan.

Selain asas-asas sebagaimana tersebut di atas, dalam pengelolaan anggaran BUN Belanja Lainnya juga perlu memperhatikan asas-asas umum pemerintahan yang lain yang terkait, diantaranya asas-asas dalam pengelolaan keuangan negara.

Apabila dikaitkan dengan pengelolaan anggaran dalam kerangka keuangan negara tersebut, dipandang sebagai suatu tindakan pejabat publik dalam penyelenggaraan pemerintahan, maka asas-asas dalam pengelolaan keuangan negara memiliki kesesuaian dengan AUPB. Prinsip yang terkandung dalam pengelolaan keuangan negara sebagaimana diatur dalam Pasal 3 ayat (1) Undang-Undang Nomor 17 Tahun 2003 tentang Keuangan Negara menyebutkan bahwa keuangan negara dikelola secara tertib, taat pada peraturan perundang-undangan, efisien, ekonomis, efektif, transparan, dan bertanggung jawab dengan memperhatikan rasa keadilan dan kepatutan. Asas-asas pengelolaan keuangan negara tersebut selaras dengan asas-asas umum penyelenggaraan pemerintahan yang baik ${ }^{47}$.

\subsection{Kebijakan Pengelolaan Anggaran BA 999.08 Sebagai Diskresi Tindakan Pemerintahan dalam Pengelolaan Anggaran Negara}

Tjandra (2009) menyatakan bahwa pengertian anggaran negara dapat dilakukan berdasarkan tiga sudut pendekatan, yaitu:

a. Sudut administratif, yang ditinjau dari sudut penatausahaan penerimaan dan pengeluaran negara dengan memperhatikan keseimbangan yang logis antara keduanya;

47 Rr. Herini Siti Aisyah, Prinsip-Prinsip Hukum Tentang Pengawasan Dalam Sistem Hukum Keuangan Negara, Disertasi (Surabaya: Program Doktor Ilmu Hukum Universitas Airlangga, 2013), hlm. 73. 
b. Sudut konstitusi, yaitu hak turut menentukan anggaran negara dari perwakilan rakyat yang pada umumnya dicantumkan dalam konstitusi suatu negara.

c. Sudut undang-undang/peraturan pelaksanaan, yaitu keseluruhan undang-undang yang diterapkan secara periodik, yang memberikan kekuasaaan eksekutif untuk melaksanakan pengeluaran mengenai periode tertentu dan menunjukkan alat pembiayaan yang diperlukan untuk menutup pengeluaran tersebut. Ditinjau dari sudut Hukum Tata Negara, APBN menitikberatkan pada aspek otorisasi. 48

Saidi (2014) menyatakan bahwa, anggaran negara merupakan tindakan atau perbuatan hukum yang dilakukan oleh Presiden bersama DPR yang memiliki fungsi berbedabeda berdasarkan sudut kajian yang dilakukan. Dalam kajian ilmu hukum, fungsi anggaran negara dapat dikaji dari aspek hukum tata negara, dan hukum administrasi karena proses penyusunan sampai dengan pengesahan dan substansi yang dikandung mengacu pada kedua cabang ilmu hukum tersebut ${ }^{49}$. Lebih lanjut, dikatakan bahwa fungsi anggaran negara dari kajian hukum administrasi tertuju pada penguasaan dan pelaksanaan anggaran negara oleh Presiden beserta pembantu-pembantunya, dalam kapasitas Presiden sebagai Chief Financial Officer sementara para menteri selaku pembantu Presiden sebagai Chief Operational Officer, kecuali Menteri Keuangan yang berada dalam kedudukan sebagai Chief Operational Officer karena mempeoleh mandat maupun sebagai Chief Financial Officer, karena memperoleh delegasi dari Presiden ${ }^{50}$.

Selaku pengelola fiskal, Menteri Keuangan yang sekaligus merupakan Pengguna Anggaran BUN melaksanakan pengelolaan anggaran yang tidak dilakukan oleh Kementerian/Lembaga pada umumnya. Pengelolaan anggaran dalam hal belanja antara lain meliputi hibah, subsidi, pembayaran bunga utang, transfer ke daerah, dan lairinya. Dalam

48 Lihat W. Riawan Tjandra, Hukum Keuangan Negara (Jakarta: Grasindo, 2009), hlm. 6.

49 Lihat Muhammad Djafar Saidi, Op. Cit., hlm. 56

50 Lihat ibid., hlm. 57. hal pendapatan, antara lain meliputi pendapatan hibah dan lainnya. Dalam hal pembiayaan, antara lain meliputi investasi, biaya management dan commitment fee Utang Luar Negeri, serta buyback SUN. Pengelolaan BUN tersebut semuanya merupakan bentuk intervensi Pemerintah dalam rangka kebijakan fiskal dengan tujuan kesejahteraan rakyat.

Terkait pengelolaan belanja lainnya, Pasal 107 Peraturan Pemerintah Nomor 45 Tahun 2013 mengatur tentang penyedian dana untuk belanja lain-lain dengan menyebutkan bahwa dalam melaksanakan kegiatan yang bersifat mendesak, tidak terduga/tidak tersangka, dan strategis serta tidak diharapkan berulang, dan pengeluaran lainnya yang sangat diperlukan dalam APBN disediakan alokasi anggaran belanja lain-lain. Ketentuan lebih lanjut, terkait pengelolaan BA BUN Belanja Lainnya (BA 999.08), sebagaimana selanjutnya diatur melalui Peraturan Menteri Keuangan Nomor 87/PMK.02/2015 menjadi dasar bagi kementerian/lembaga untuk melaksanakan kegiatan yang didanai dengan menggunakan BA BUN Belanja Lainnya (BA 999.08).

Dalam ketentuan Pasal 2 Peraturan Menteri Keuangan Nomor 87/PMK.02/2015 disebutkan Menteri Keuangan selaku Pengguna Anggaran BUN berwenang menetapkan penggunaan anggaran pada BA 999.08 dalam tahun anggaran berjalan sebagaimana ditetapkan dalam APBN dan/atau APBN Perubahan. BA 999.08 sebagaimana dimaksud dalam Pasal 2, menurut jenis belanja terdiri atas:
a. belanja pegawai;
b. belanja bantuan sosial; dan
c. belanja lain-lain.

Khusus untuk belanja lain-lain, dalam ketentuan Pasal 7 ayat (1) disebutkan bahwa penggunaan anggaran BA 999.08 jenis belanja lain-lain pos cadangan keperluan mendesak dan pos pengeluaran lainnya di luar pos cadangan keperluan mendesak digunakan untuk membiayai kegiatan yang memenuhi kriteria sebagai berikut:

a. memiliki dasar hukum paling rendah ditetapkan oleh Presiden atau berupa direktif Presiden yang ada di dalam risalah sidang kabinet/ rapat terbatas - kabinet yang diterbitkan oleh Sekretariat Kabinet;

b. kegiatan yang diusulkan tidak direncanakan dalam proses 
penyusunan anggaran kementerian negara/lembaga berkenaan;

c. dana untuk kegiatan yang diusulkan tidak cukup tersedia dalam DIPA kementerian negara/lembaga berkenaan dan tidak memungkinkan untuk dilakukan realokasi antar program maupun kegiatan;

d. kegiatan yang diusulkan tidak bersifat rutin; dan

e. dari sisi waktu atas pelaksanaan kegiatan yang diusulkan, tidak memungkinkan untuk diajukan dalam APBN-Perubahan.

Meskipun pada ketentuan Pasal 7 ayat (1) telah disebutkan kriteria kumulatif kegiatan yang dapat dibiayai dengan pos belanja lain-lain, tapi dalam ketentuan Pasal 7 ayat (2) disebutkan pengecualian penggunaan kriteria dimaksud untuk keadaan tertentu sebagai berikut:

a. kegiatan yang diusulkan adalah sebagai akibat dari keadaan kahar;

b. kegiatan yang diusulkan bersifat tidak terduga, namun sangat diperlukan dalam rangka penyelenggaraan kewenangan Pemerintah Pusat;

c. kegiatan yang diusulkan mempunyai risiko yang besar apabila tidak dipenuhi pada saat kejadian, baik dari segi politik, ekonomi, sosial, dan keamanan; dan/ atau

d. kegiatan yang diusulkan terkait dengan kebijakan Pemerintah Pusat dan harus segera dilaksanakan.

Dalam ketentuan Pasal 11 disebutkan, setelah mendapatkan persetujuan Menteri Keuangan, selanjutnya atas usulan penggunaan anggaran dimaksud Direktur Jenderal Anggaran Kementerian Keuangan, akan menerbitkan dokumen pelaksanaan anggaran dalam bentuk SP-SABA, SPP BUN, atau DIPA BUN.

Untuk kegiatan yang dibiayai dengan anggaran dalam DIPA BUN, maka selanjutnya Menteri Keuangan akan mengeluarkan kebijakan yang secara spesifik mengatur pelaksanaan kegiatan dimaksud. Sebagai contoh, pada kegiatan ongkos angkut beras untuk PNS di distrik pedalaman Provinsi Papua dan Papua Barat, Menteri Keuangan mengeluarkan Peraturan Menteri Keuangan Nomor 207/PMK.03/2014. Kegiatan ongkos angkut beras memiliki kebijakan pengaturan tersendiri. Sejatinya penggunaan anggaran pada BA 999.08 ditujukan pada kegiatan-kegiaan yang bukan merupakan tugas dan fungsi Kementerian Keuangan dan dilaksanakan oleh Kementerian/Lembaga maupun pihak terkait (mis. Pemerintah Daerah) yang menaungi tugas dan fungsi kegiatan dimaksud, setelah mendapat persetujuan dari Menteri Keuangan. Namun, untuk kegiatan tertentu, sebagai contoh kegiatan ongkos angkut beras, dalam pelaksanaannya terdapat diskresi Menteri Keuangan untuk melibatkan unit kerja di lingkungan Kementerian Keuangan selaku KPA, meskipun kegiatan dimaksud bukan bagian dari tugas dan fungsi Kementerian Keuangan.

Memperhatikan uraian terkait pengaturan dalam kebijakan pengelolaan BA BUN Belanja Lainnya sebagaimana tersebut di atas, nampak jelas peran Menteri Keuangan selaku pengelola fiskal yang menjalankan fungsi Bendahara Umum Negara dalam menetapkan kebijakan-kebijakan yang berkenaan dengan pengelolaan BA BUN. Namun demikian, dalam pengambilan kebijakan-kebijakan dimaksud, sebagai suatu tindakan pemerintahan yang berdimensi publik, seyogyanya diskresi yang dilakukan tetap harus memperhatikan kaidahkaidah tata kelola pemerintahan yang baik karena hal tersebut berkaitan dengan keabsahan tindakan serta konsekuensi yuridis dari setiap kebijakan yang dilakukan.

Terkait kebijakan pengelolaan anggaran Belanja Lainnya sebagai bagian pengelolaan anggaran negara yang bersifat diskretif tersebut, Suyanto (2015) menyatakan bahwa wewenang diskresi pada tindakan pemerintahan muncul sebagai solusi agar pelaksanaan pemerintahan tetap dapat berjalan efektif walaupun terdapat kondisi-kondisi yang sifatnya force majeur.

Sebuah sistem pengelolaan keuangan pemerintah yang baik adalah bilamana sistem tersebut mampu mendukung kegiatan unit-unit pemerintahan dalam jajarannya, tanpa menimbulkan kendala dalam situasi apa pun. Pemikiran inilah yang muncul dan menjadi acuan pengelola keuangan negara ketika menghadapi kendala berbagai ketentuan pengelolaan keuangan negara yang tidak fleksibel, sehingga muncul sebagian pendapat bahwa sepanjang dananya tersedia dalam anggaran negara, atau terdapat keadaan yang membutuhkan suatu tindakan cepat pemerintah, seharusnya pemerintah memiliki keleluasaan untuk menggunakan dana yang tersedia, atau 
setidak-tidaknya menggeserkan dana yang disediakan untuk kepentingan lain yang untuk sementara waktu belum digunakan. Pemikiran seperti inilah yang kemudian melahirkan gagasan tindakan pengelolaan keuangan yang bersifat diskretif. Tindakan diskretif itu lahir karena belum adanya aturan (regulasi) yang dipicu oleh adanya suatu keadaan yang memaksa (force majeur) ${ }^{51}$.

Pendapat serupa terkait penggunaan kebijakan dalam pengelolaan anggaran negara dalam keadaan tertentu juga disampaikan Saidi (2014), dalam konteks pergeseran anggaran sebagai berikut:

Pergeseran anggaran negara tidak boleh dilakukan ketika tidak berada dalam keadaan force majeur terhadap suatu kegiatan yang memerlukan pembiayaan yang secara mendesak dan harus ditanggulangi secara seketika saat itu. Pelaksanaan pergeseran anggaran negara merupakan freis ermessen yang berada pada pengelola keuangan negara, baik di tingkat pusat maupun di daerah yang pembiayaannya bersumber dari anggaran negara. Kebijakan itu tetap berada dalam lingkup koridor hukum, artinya freis ermessen tidak boleh dilakukan tatkala menyimpang atau bertentangan dengan ketentuan peraturan perundang-undangan yang berlaku. ${ }^{52}$

Lebih lanjut terkait kebijakan diskretif dalam pelaksanaan anggaran negara, Sujanto (2015) menyatakan bahwa di sisi pelaksanaan anggaran, berbagai keputusan yang bersifat diskretif harus dilakukan dengan tetap mengacu pada paradigma yang menyatakan bahwa pelaksanaan anggaran merupakan operasionalisasi sebuah keputusan politik ,dalam hal ini, APBN yang merupakan hasil kesepakatan anggaran negara antara Pemerintah dan DPR sebagai representasi

51 Lihat Siswo Sujanto, Diskresi Keuangan Ditinjau dari Perspektif Undang-Undang Bidang Keuangan Negara Dan Penyelesaian Kasus Korupsi, Makalah, disajikan dalam Seminar yang diselenggarakan oleh Direktorat Jenderal PerbendaharaanKementerian Keuangan, Jakarta, tanggal 23 Desember 2015.

52 Muhammad Djafar Saidi, Op. Cit., hlm. 66-67. rakyat. Terkait dengan hal tersebut, diskresi yang mungkin dilakukan hanya mencakup bagaimana operasi pelaksanaan kegiatan penerimaan dan pengeluaran negara dapat tetap dilaksanakan ketika terjadi situasi yang tidak seperti biasanya. Namun dalam hal ini, langkah-langkah diskretif yang diambil harus tetap berpatokan pada prinsip kehati-hatian (prudential principle) untuk menghindarkan terjadinya kerugian negara ${ }^{53}$.

Dengan demikian, pelaksanaan kebijakan dalam pengelolaan anggaran BUN Belanja Lainnya yang diperuntukkan bagi kegiatankegiatan yang sifatnya mendesak dan/atau tidak terduga, dapat dilakukan oleh Bendahara Umum Negara sepanjang masih dalam koridor hukum dan mematuhi asas/prinsip-prinsip pengelolaan keuangan negara guna menghindari tejadinya kerugian negara. Terlebih, kebijakan yang diambil Bendahara Umum Negara dalam pengelolaan Belanja Lainnya lebih bersifat operasional yang mencakup bagaimana pelaksanaan kegiatan dapat tetap dilaksanakan ketika terjadi situasi yang tidak seperti keadaan biasanya. Dalam kaitan Pengelolaan Belanja Lainnya, keadaan tertentu dimaksud berbeda untuk tiap jenis belanjanya. Untuk belanja pegawai, keadaan tertentu dapat berkaitan dengan adanya penambahan formasi pegawai sehingga membutuhkan tambahan belanja pegawai untuk membayar penggajian pegawai baru yang belum dialokasikan anggarannya pada DIPA Kementerian/Lembaga. Untuk belanja bantuan sosial, berkaian dengan keadaan kahar/force majeur yang memerlukan penanganan segera/mendesak. Sedangkan untuk belanja lain-lain yang berkaitan dengan dana cadangan, misalnya dana cadangan beras, digunakan untuk pemenuhan kebutuhan pangan yang mendesak.

Memperhatikan hal tersebut di atas, pengambilan kebijakan dalam pengelolaan anggaran BA 999.08 yang diperuntukkan bagi kegiatan-kegiatan yang sifatnya mendesak dan/atau tidak terduga, dapat dilakukan oleh Bendahara Umum Negara sepanjang masih dalam koridor hukum dan mematuhi prinsipprinsip pengelolaan keuangan negara guna menghindari tejadinya kerugian negara. Pengelolaan anggaran negara dalam pengelolaan anggaran BUN Belanja Lainnya sebagai bagian dari pengelolaan anggaran negara juga perlu dilakukan dengan tetap

\footnotetext{
53 Lihat ibid.
} 
memperhatikan ketentuan peraturan perundang-undangan dan taat asas dalam rangka mewujudkan pengelolaan keuangan negara yang tertib, taat peraturan, efisien, ekonomis, efektif, transparan dan bertanggung jawab.

\section{KESIMPULAN DAN SARAN \\ 5.1. Kesimpulan}

Berdasarkan uraian sebagaimana pembahasan tersebut di atas, dapat diambil kesimpulan bahwa kebijakan pengelolaan anggaran BA 999.08 merupakan salah satu kebijakan di bidang pengelolaan anggaran negara yang menjadi kewenangan Menteri Keuangan selaku pengelola fiskal dalam menjalankan salah satu fungsinya sebagai Bendahara Umum Negara sebagaimana maksud ketentuan Pasal 8 huruf $\mathrm{f}$ Undang-undang Nomor 17 Tahun 2003 jo. Pasal 7 Undangundang Nomor 1 Tahun 2004. Oleh karena karakteristiknya yang berbeda dengan anggaran belanja negara pada umumnya, sesuai ketentuan Pasal 110 Peraturan Pemerintah Nomor 45 Tahun 2013, Menteri Keuangan diberikan kewenangan discretionarie untuk mengatur lebih lanjut kebijakan terkait pengelolaan anggaran dimaksud. Untuk mengukur keabsahan kebijakan dimaksud, dapat dilihat kesesuaian dari sisi wetmatiegheid dalam peraturan perundang-undangan yang terkait, maupun rechtmatiegheid dengan parameter Asas-asas Umum Pemerintahan yang Baik (AUPB).

Kebijakan pengelolaan anggaran BA.999.08 sebagaimana diatur dalam Peraturan Menteri Keuangan Nomor 231/PMK.02/2015 jo. Peraturan Menteri Keuangan Nomor 87/PMK.02/2015, merupakan kebijakan Menteri Keuangan yang bersifat discretionarie sebagai bagian dari pengelolaan anggaran negara secara umum. Pelaksanaan kebijakan dalam pengelolaan anggaran BUN Belanja Lainnya dilakukan untuk memastikan tetap terlaksananya pengelolaan anggaran negara untuk membiayai kegiatan yang anggarannya tidak termasuk dalam bagian anggaran Kementerian/Lembaga serta sifatnya mendesak dan/atau tidak terduga.

\subsection{Saran}

Pengaturan dalam Peraturan Menteri Keuangan Nomor 87/PMK.02/2015 telah memberikan landasan hukum kebijakan pengelolaan anggaran BA.999.08 dengan tujuan agar pengelolaan anggaran yang tidak dikelompokkan dalam bagian anggaran Kementerian/Lembaga dan sifatnya mendesak dan/atau tidak terduga tetap dapat terlaksana sehingga tetap menjamin terpenuhinya hak-hak pihak yang terkait dengan penggunaan anggaran dimaksud. Namun demikian, sebagai salah satu bentuk kebijakan yang dilakukan oleh Menteri Keuangan selaku pejabat publik, dalam rangka menjamin keabsahan kebijakan pengelolaan Bagian Anggaran Bendahara Umum Negara Belanja Lainnya, pelaksanaannya harus mengacu pada peraturan perundang-undangan serta mempedomani AUPB yang juga tercermin dalam asas-asas pengelolaan keuangan negara dalam rangka mewujudkan pengelolaan keuangan negara yang tertib, taat pada peraturan perundang-undangan, efisien, ekonomis, efektif, transparan dan bertanggung jawab dengan memperhatikan rasa keadilan dan kepatutan sebagaimana maksud dari asas-asas pengelolaan keuangan negara tersebut.

\section{DAFTAR PUSTAKA}

Aisyah, Rr. Herini Siti. (2013). Prinsip-Prinsip Hukum Tentang Pengawasan Dalam Sistem Hukum Keuangan Negara, Disertasi, Program Doktor Ilmu Hukum Universitas Airlangga, Surabaya.

Asshiddiqie, Jimly. (2008). Pokok-Pokok Hukum Tata Negara Indonesia Pasca Reformasi. Bhuana Ilmu Populer, Cetakan II, Jakarta.

Basah, Sjachran. (1997). Eksistensi dan Tolok Ukur Peradilan Administrasi di Indonesia, Alumni, Bandung.

Black, Henry Campbell. (1990). Black'S Law Dictionary, West Publishing, Minnesotta.

Djatmiati, Tatiek Sri. (2004). Prinsip-prinsip Izin Usaha Industri di Indonesia, Disertasi, Program Pasca Sarjana Universitas Airlangga, Surabaya, 2004.

Hadjon, Philipus M. (1997), Tentang Wewenang, Yuridika, No. 5 \& 6 Tahun XII.

Hadjon, Philipus M. (2004). Discretionary Power dan Asas-Asas Umum Pemerintahan Yang Baik (AAUPB), Paper/Makalah, disampaikan pada Seminar Nasional "Aspek Pertanggung jawaban Pidana Dalam Kebijakan Publik Dari Tindak Pidana Korupsi", Semarang.

Hadjon, Philipus M. (tanpa tahun). Beberapa Catatan Tentang Hukum Administrasi, 
Makalah, tidak dipublikasikan, Fakultas Hukum Universitas Airlangga, Surabaya.

Hadjon, Philipus M. dan Tatiek Sri Djatmiati. (2008). Argumentasi Hukum, Cetakan III, Gajah Mada University Press, Yogyakarta.

Hadjon, Philipus M., et al.(2011). Hukum Administrasi dan Tindak Pidana Korupsi, Gadjah Mada University Press, Yogyakarta, 2011.

Hadjon, Philipus M., et al.(2010). Hukum Administrasi dan Good Governance, Universitas Trisakti, Jakarta.

Hadjon, Philipus M., et al.(1994). Pengantar Hukum Administrasi Indonesia, Gadjah Mada University Press, Yogyakarta, 1994.

HR., Ridwan. (2013). Hukum Administrasi Negara Edisi Revisi, Cetakan. 8, Rajawali Pers, Jakarta.

HR., Ridwan. (2014). Diskresi dan Tanggung Jawab Pemerintah, FH UUI Press, Yogyakarta.

Marbun, S.F. (2014). Asas-Asas Umum Pemerintahan Yang Layak, Cetakan I, FH UII Press, Yogyakarta.

Marzuki, Peter Mahmud. (2015). Penelitian Hukum, Edisi Revisi, Cetakan. Ke-10, Kencana Pranadamedia Group, Jakarta.

Marzuki, Peter Mahmud. (2014). Pengantar Ilmu Hukum, Edisi Revisi, Cetakan Ke-16, Kencana Pranadamedia Group, Jakarta.

Pratiwi, Cekli Setya, et. al.(2016). Penjelasan Hukum Asas-Asas Umum Pemerintahan yang Baik (AUPB), Hukum Administrasi Negara, Judicial Sector Support Program Mahkamah Agung RI, Jakarta.

Purbopranoto, Kuntjoro. (1975). Beberapa Catatan Hukum Tata Pemerintahan dan Peradilan Administrasi Negara, Bina Cipta, Bandung.

Saidi, Muhammad Djafar. (2014). Hukum Keuangan Negara, Edisi Revisi, Cetakan Ke-4, Rajawali Press, Jakarta.

Sibuea, Hotma P. (2010). Asas Negara Hukum, Peraturan Kebijakan, dan Asas-Asas Umum Pemerintahan yang Baik, Penerbit Erlangga, Jakarta.

Sujanto, Siswo. (Desember 2015). Diskresi Keuangan Ditinjau dari Perspektif UndangUndang Bidang Keuangan Negara Dan
Penyelesaian Kasus Korupsi, Makalah, disajikan dalam Seminar yang diselenggarakan oleh Direktorat Jenderal Perbendaharaan-Kementerian Keuangan, Jakarta.

Tjandra, W. Riawan. (2009). Hukum Keuangan Negara, Grasindo, Jakarta. 